\title{
Model uzročno-posljedičnih veza osmanske ugroze, klimatskih nepogoda, gladi i kuge na privredu hrvatskih i slavonskih vlastelinstava u zadnjim desetljećima 15. i tijekom 16. stoljeća
}

Prethodno priopćenje
Preliminary communication

UDK 338.124.4(497.5)“14/15“

Osiromašeno gospodarstvo hrvatskih zemalja u razdoblju od pada Bosne pod osmansku vlast pa do trenutka kada je Korvinov obrambeni protuosmanski granični sustav (1463.-1527.) kolabirao, postupno je poprimalo gotovo apokaliptične dimenzije. Najvažniji i u povijesnim procesima najvidljiviji mehanizmi krize koji su rezultirali potpunim gospodarskim slomom srednjovjekovnih hrvatskih zemalja su: 1) ratovi kršćanskih i osmanske države koji su se vodili na hrvatskim teritorijima; 2) sve učestaliji pljačkaški pohodi osmanskih (ne)regularnih postrojbi na hrvatskim područjima (mali rat); 3) zdravstvene (ne)prilike (kuga i druge pošasti); 4) klimatske promjene koje su nastupale od kraja 15. st. (malo ledeno doba); 5) posvemašnja depopulacija središnjih hrvatskih područja kao rezultat prethodno spomenutih čimbenika. Autor u radu opisuje rezultate navedenih procesa na gospodarstvo veleposjeda i gradova u Hrvatskoj i Slavoniji.

Ključne riječi: osmanska opasnost, kužne epidemije, klimatske promjene, depopulacija, gospodarstvo, Hrvatska i Slavonija

\section{Čimbenici gospodarskog sloma}

Gospodarstvo je hrvatskih zemalja u razdoblju od pada Bosne pod osmansku vlast $J_{(1463 .)}$ pa do katastrofe na Mohaču (1526.) ovisilo o djelotvornosti obrambenoga protuosmanskog sustava koji je osmislio i izgradio kralj Matija Korvin. Kao što je taj sustav postupno slabio u vrijeme Jagelovića i naglo se počeo urušavati padom Beograda (1521.) tako je i gospodarstvo hrvatskih zemalja postupno, odnosno naglo, nestajalo i poprimalo gotovo apokaliptične dimenzije. Zamršenost gospodarskih i društvenih odnosa tijekom tog razdoblja onemogućava autora da u ovom tekstu pruži detaljan prikaz svih uzroka gospodarskog nazadovanja i propadanja hrvatskih zemalja koje je trajalo tijekom čitava 16. stoljeća. Valja ipak upozoriti da su rubna područja hrvatskih zemalja (Dubrovačka Republika, dalmatinsko otočje s urbanim središtima i sjeverozapadni dio Slavonije) na kojima se nisu 
znatnije osjećale posljedice malog rata ipak zadržala pravac gospodarskoga predosmanskog razvitka (Raukar 1997: 407-475).

Među presudnim čimbenicima koji su utjecali na gospodarsko stanje hrvatskih zemalja valja, uz redovito spominjana ratna pustošenja, istaći i usko povezane klimatske promjene i zdravstvene prilike žiteljstva, koje su uzajamnim djelovanjem ostavljale iza sebe pustoš ne samo na tim prostorima, već i na širem teritoriju tadašnjeg Mediterana. Zadnjih desetljeća 15. i kroz čitavo 16. st. vremenske su nepogode i kužne epidemije izazvale teške godine krize u ionako narušenim gospodarskim, društvenim i ratnim prilikama tadašnje hrvatske svakodnevice. Onodobni su crkveni i svjetovni službenici u svojim izvješćima opisivali posljedice neuobičajeno oštrih i dugih zima. Spominju se uništeni i zaleđeni vinogradi, maslinici i usjevi, ili smrznute bačve vina, ali i vina koje se ledilo u kaležima pod sv. misom (!), a ljudima su prema tim vijestima otpadali smrznuti nosovi, prsti i uši. Opisuju se također ljudi koji iznureni od gladi bauljaju po gradovima i prose koricu kruha ili bilo kakvu hranu te jedu travu i koru s drveća, ali i sveprisutnu smrt tijekom epidemija kuge te ljudi koji bezglavo bježe iz "crnom smrću“ pogođenih mjesta (Kukuljević 1857; Adamček et al. 1976; Kužić 2000). Najvažniji, dakle, i u povijesnim procesima najvidljiviji mehanizmi krize koji su polučili gospodarskim slomom srednjovjekovne Hrvatske i Slavonije u 16. stoljeću jesu:

1. ratovi kršćanskih i osmanske države koji se vode na hrvatskim teritorijima;

2. sve učestaliji pljačkaški pohodi osmanskih (ne)regularnih postrojbi na hrvatska područja (mali rat);

3. zdravstvene (ne)prilike (kuga i druge pošasti);

4. klimatske promjene koje nastupaju potkraj 15. st. (malo ledeno doba);

5. posvemašnja depopulacija središnjih hrvatskih područja kao rezultat prethodno spomenutih čimbenika.

\section{Spirale smrti}

Premda su, dakle, suvremeni kroničari upozoravali na veze između posljedica ratnih razaranja, pustošenja osmanskih martolosa i akindžija, elementarnih nepogoda, gladnih godina i pojava epidemija kuge, one su uglavnom ostajale izvan glavnog fokusa interesa i hrvatskih i povjesničara s područja srednje i jugoistočne Europe. Takve su se pojave, međutim, u zapadnoj Europi proučavale. Naime, francuski su znanstvenici, povjesničari klimatologije i medicine Ladurie i Biraben, proučavajući vijesti slične onima koje se nalaze u onodobnim hrvatskim dokumentima (kronike, izvješća državnih službenika, urbari vlastelinstava itd.) došli do zaključka kako su se upravo u to vrijeme dogodile klimatske promjene koje se mogu okarakterizirati kao malo ledeno doba i kako se te promjene mogu dovesti u svezu s godinama gladi i potom s pojavama kužnih epidemija (Ladurie 1972: 244-308 i 334-394; Biraben 1975: 7-9, 134-139 i 147-154). Biraben je zaključio kako je u pravilu glavni preduvjet pojave kužne epidemije zdravstveno iscrpljena ljudska zajednica koja proživljava ili je upravo preživjela razdoblje gladi. Stoga se na bazi njegovih rezultata čitav uzročno-posljedični proces pojave kužne epidemije može predočiti shemom:

elementarna nepogoda $\rightarrow$ razdoblje gladi $\rightarrow$ kužna epidemija $\rightarrow$ razdoblje gladi (Biraben 1976: 2-27).

Slična se "spirala smrti“ može primijeniti i za tadašnju Hrvatsku. Razlika je i dodatnomu destabilizirajućem faktoru osmanskih pustošenja, koji je iznova odgađao trenutak prestanka ciklusa činitelja vezanih za pojave kužne epidemije i povratka u mirno razdoblje života i proizvodnje. Vremenske su nepogode, osobito oštre dugotrajne zime i hladna proljeća, zasigurno teže pogađale kontinentalno zaleđe, preciznije osmansku Bosnu, od dalmatinskih 
gradova i primorskih područja Hrvatske. Nakon takvih nepogoda koje su ostavljale iza sebe nerodicu i pustoš u Dalmaciji i Hrvatskoj, nije bivala začudnom pojava bosanskih osmanskih pljačkaških postrojbi na teritorijima susjednih kršćanskih država. Bosanskom je žiteljstvu u tim slučajevima, dakle, "pljačkaško gospodarstvo“ bilo jedinim izlazom iz prijeteći nastupajuće gladne godine. Stoga bi shema za hrvatske zemlje izgledala ovako:

elementarna nepogoda $\rightarrow$ godina gladi $\rightarrow$ osmansko pustošenje $\rightarrow$ kužna epidemija $\rightarrow$ godina gladi.

Kakvo je, dakle, demografsko i gospodarsko stanje bilo na hrvatskim i slavonskim veleposjedima i u gradovima nakon prestanka djelovanja opisanih „spirala smrti“?

\section{Veleposjedi i „spirale smrti“}

Zoran primjer suodnosa elementarne nepogode, gladne godine i pojave kužne epidemije (Birabenova shema - op. a.), a potom i iseljavanja seljaka u strane zemlje, jest onaj iz 1517. god. na samoborskom vlastelinstvu velikaške obitelji Erdődy. U registru poreza za to vlastelinstvo navedeno je kako su seljaci 34 domaćinstva zbog gladi odselili u njemačke (najvjerojatnije u susjednu Kranjsku ili Štajersku - op. a.) zemlje ${ }^{1}$ dok su članovi čak 46 domaćinstva nedavno pomrli zbog zarazne bolesti². Izrazito se teško stanje vlastelinstva ogleda i u činjenici da su seljaci 44 domaćinstava bili te godine oslobođeni poreza, ${ }^{3}$ jer su ostali bez uroda zbog dugotrajne zime (Adamček et al. 1976: 21 i 86-87). Upravo zbog djelovanja ciklusa objašnjenog Birabenovom shemom posjednička obitelj Erdődy nije mogla prikupiti poreze s čak $53,5 \%$ seljačkih posjeda od kojih su, kao što smo naveli, 80 ili gotovo $35 \%$ navedeni kao novoopustjeli ${ }^{4}$. Ti podaci govore i o ubrzanim gubicima u ljudskom potencijalu jedne regije i o značajnom opadanju gospodarske stabilnosti hrvatskih i slavonskih feudalaca, koji su potom sve nemoćniji u ispunjavanju svoje osnovne plemićke zadaće - zaštiti svojih posjeda i obrani Kraljevstva.

Sličnu su ivrlo važnu ulogu u ubrzanom procesu urušavanja obrambenog protuosmanskog sustava u Hrvatskoj tijekom dvadesetih godina 16. st. odigrali i činitelji ciklusa naše sheme. Suodnos ratnih razaranja, pustošenja, vremenskih nepogoda, gladi i pojava kuge dovodio je do potpune depopulacije hrvatskih područja u zaleđu dalmatinskih gradova i do osmanskog neometanog zaposjedanja tih područja. Primjerice, tijekom izuzetno hladne zime 1523.1524. i potom nastupajuće gladi u proljetnim mjesecima 1524. god., osmanski su prepadi postajali sve učestaliji i okrutniji (Hodinka et al. 1903: 273-274 i 318-321; Kukuljević 1865: 188, 190 i 196-197). Stanje se pogoršalo pojavom kuge koja se proširila iz Bosne tijekom travnja mjeseca te iste godine, a napose je teško razdoblje nastupilo nakon opetovane ledene zime 1524.-1525. (Kukuljević 1857: 40; 1865: 191). Tog su se proljeća osmanske provale s prethodno opustošenih područja šibenskoga, zadarskog, trogirskog i splitskog zaleđa preusmjerile više na zapad k frankapanskim vlastelinstvima Modrušu, Vinodolu i Ozlju (Kukuljević 1865: 200, 211, 231, 333, 358 i 421), a upravo je tih mjeseci dovršena i konačna depopulacija županija Krbave i Like, koje je držao posljednji izdanak moćnih Kurjakovića Krbavskih - grof Ivan Karlović (Ljubić 1876: 185-188; 1877: 13). Čitavo je to područje do god. 1527. potpalo pod osmansku vlast koja je zaposjela županije Hotuču, Krbavu, Liku i dijelove Luke bez znatnijega vojnoga otpora (Laszowski 1914: 6-7). U svakom slučaju, uz osmanski, koji je relativno dobro obrađen u hrvatskoj historiografiji, morat će se u budućim

\footnotetext{
... deserti fumi qui ad partes Alemanorum discesserunt...

... deserti noviter per mortem pestilentam post dicam preteritam...

... pauperes ad juramentum judicis relaxtati...

... deserti fumi noviter...
} 
istraživanjima ozbiljno uzimati u obzir i preostali spomenuti čimbenici (elementarne nepogode, godine gladi, kužne epidemije) koji su doveli do potpunoga populacijskog sloma, a time i uništenja gospodarstva, raspada društvenih odnosa i konačnog gubitka navedenoga patrimonija Kurjakovića Krbavskih, dakle, središnjih hrvatskih teritorija (kao što je to dijelom uzeo u obzir Botica 2011: 228-299).

Razdoblje ubrzanog opadanja gospodarske moći hrvatskog društva započinje u trenutku kada sultan Muhamed II. uspijeva osvajanjem Srbije i Bosne (1459. i 1463.) doprijeti na granice Ugarsko-Hrvatskog Kraljevstva. Od tog vremena pa do konačnoga sloma Korvinova obrambenog sustava (1521.-1527.), većina je hrvatskog plemstva, osobito onoga koje je imalo posjede uz samu granicu s osmanskom Bosnom, potpuno ili u znatnijoj mjeri izgubila poljoprivrednu gospodarsku osnovu. Takav trend nazadovanja zabilježen je i na velikaškim posjedima, koji nisu bili na samoj granici, već su, štoviše, bili u zaleđu obrambenoga protuosmanskoga vojnog sustava.

Urbar modruškog vlastelinstva grofa Bernardina Frankapana iz 1486. god., primjerice, sasvim jasno pokazuje vrlo teško gospodarsko stanje tog, u to vrijeme, najmoćnijeg hrvatskog magnata. Iz urbara se vidi da je gotovo dvije trećine stanovništva već izbjeglo s vlastelinstva (434 opustošena i napuštena selišta i samo 270 naseljenih) pa je Bernardin preostalim podložnicima bio prisiljen potvrditi selišta pod vrlo povoljnim uvjetima s ciljem da i to preostalo žiteljstvo ne odseli s njegovih imanja (Lopašić 1894: 27-34; Klaić 1972: 344-350; Kruhek 2008: 41-60). Štoviše, on im je dozvolio obradu i više zemljišnih čestica smanjujući im istovremeno dužna podavanja s tih čestica. Uz te je povoljne uvjete bio pripravan prihvatiti u teškim vremenima i porez za koji sami seljaci budu smatrali da mu ga mogu dati (Klaić 1972: 344; Frankapan 2010: 40-42). Taj, kao i ostali urbari pisani do sredine 16. st. predstavljaju autentičnu sliku gospodarskog stanja na hrvatskim i slavonskim vlastelinstvima neposredno prije osmanskih osvajanja graničnih županija (Klaić 1972: 325-330; Kruhek 2008: 41-60). ${ }^{5}$

Vlastelinstva su magnata, dakle, postupno propadala, jer su ih pod pritiscima ratne opasnosti, elementarnih nepogoda, kuge i gladi obrađivači napuštali tražeći sigurnija mjesta življenja na Apeninskom poluotoku, susjednim njemačkim zemljama te posebice u zapadnim ugarskim županijama (Kampuš 1995; Gestrin 1998; Čoralić 2001). Stoga su hrvatski velikaši sve češće prihvaćali vojnu plaćeničku službu i novčanu državnu pripomoć za uzdržavanje svojih banderijalnih vojski kao prihvatljivu i korisnu alternativu zarade novca. No, taj im je novac bivao zapravo nadomjestak za nedostatan financijski priljev s njihovih opustjelih posjeda. Slična se praksa osobito raširila među pripadnicima srednjega i nižeg plemstva, čiji su patrimonijalni posjedi tijekom vremena bili potpuno devastirani ili, pak, izgubljeni napredovanjem osmanske sile (Raukar 1997: 420-424; Grgin 2002: 115-127).

\section{Posjedi plemenitih rodova i „spirale smrti“}

Zemlja je kao gospodarska osnova igrala značajnu ulogu i u očuvanju hrvatskih plemenitih rodova (lat. genera, generationes, starohrv. plemena), što je posve vidljivo kroz pravne odredbe i sudske procese koji su se vodili zbog patrimonija (plemenšćina) pojedinih članova tog plemstva. Nedjeljivost plemenšćine očuvala je rodovsku solidarnost pa su nestankom takvih posjedovnih odnosa automatski pucale i veze solidarnosti (Karbić 2000: 377-381; Jurković 2002: 153-157). Takav se odnos prema posjedu i članovima plemenitih rodova iskazivao i u slučajevima kada su pojedini članovi roda koji su iselili na nova područja ili u nove gradove nastojali čuvati, pa čak i uvećati, svoj udio u plemenšćini na domicilnom teritoriju (Karbić 1990: 17-24; 1998: 111-115).

Prema podacima su urbara pavlinskog posjeda Streza (županija Križevci), pisanog 1477., pavlinski kmetovi zadobili gotovo identičan privilegij onomu u Modruškom urbaru. 
Poslije pada Bosne plemeniti su rodovi u neprekinutim ratovanjima na graničnim područjima ostali bez mnogih svojih članova (puno ih je iselilo, ali također izginulo i zarobljeno u borbama). $\mathrm{U}$ tom im je razdoblju osmanskim pohodima i ostalim nepogodama (klimatskim, godinama gladi, iseljavanjima) gospodarska baza njihovih posjeda u potpunosti uništena. Pored svega toga je i otkup zarobljenih članova obitelji i roda igrao vrlo važnu ulogu u procesu uništenja njihove gospodarske moći. ${ }^{6}$ Naime, do prvoga desetljeća 16 . st. otkupnina je bivala vrlo visoka i često jednaka vrijednosti patrimonija zarobljenikove obitelji. Težak je problem otkupnine istakao i grof Bernardin Frankapan kada navodeći njemačkim staležima 1522. god. u Nürnbergu sve nevolje koje su pogodile „nesretnu domovinu Hrvatsku“ kaže kako je u Hrvatskoj ostao „vrlo mali broj ljudi koji su i sami po dva i po tri puta od Turaka prodavani i otkupljivani“ (Frankapan 2010: 109). Da bi se, pak, član obitelji otkupio moralo se često prodavati veći dio plemenšćine, što je protekom vremena bilo sve teže ostvariti, jer za nekretnine na opustjelim i ratom ugroženim područjima nitko nije bio zainteresiran (Jurković 2006: 61-63). ${ }^{7}$

Godine sloma tradicionalno ukorijenjenih plemenitih rodova u središnjoj Hrvatskoj dogodile su se poslije gore opisanih isprepletenih udara dugotrajnih zima, gladi, osmanskih pustošenja i kuge (1523.-1525.). Nije se, dakle, samo dogodila depopulacija županije Krbave, već i svih županija u međurječju Zrmanje i Cetine. Središta uglednih i moćnih plemićkih rodova na tim su prostorima ostala pusta, primjerice, Bribir roda Šubića ili Vrhrika roda Čubranića, a napuštena su i dvorna mjesta ogranaka rodova pa tako Ugrinići od roda Šubića pred Osmanlijama napuštaju svoj Rog, Draškovići od roda Kršelaca svoje Biline, Utišenići od roda Mogorovića tvrđavu Kamičac... (Jurković 2002; 2004; 2008).

Slom Korvinova obrambenog sustava (1521.-1527.) označio je, dakle, završetak započetog procesa raspadanja plemićkih zajednica temeljenih na bazi funkcioniranja rodovskih sustava u Hrvatskoj i osmanskom okupacijom središta srednjovjekovne Hrvatske nestanka gospodarske/zemljišne osnovice rodova. Upravo zato su se preostale obitelji rodovskog plemstva sve češće okretale ratnom gospodarstvu kao izvoru opstanka na ostacima Hrvatske - bilo preko vojnih službi u banderijima svjetovnih i crkvenih velikaša, bilo preko službi u kraljevskim garnizonima na granici, a isti su obrazac ponašanja zadržali i u doseljenim slavonskim i ugarskim sredinama, jer gdjegod da doselili - do tih su ih prostora tijekom 16. st. „sustizala“ osmanska osvajanja (Jurković 1999: 74-75; Jurković 2006: 46-49).

\section{Gradovi i „spirale smrti“}

Stalno ratovanje, učestale elementarne nepogode, godine gladi i kužne epidemije ostavljaju također traga i na ostalim gospodarskim aktivnostima. Jedna od bitnih posljedica takvog stanja u Hrvatskoj jest i gotovo potpuni prekid trgovačkih pravaca koji su išli preko Hrvatske u kontinentalni dio Europe i njihovo preusmjeravanje na nova neugrožena i sigurna zapadna područja. Naime, razdoblje naglog procvata tranzitne trgovine u susjednim

\footnotetext{
Problem je ratnih (civilnih i vojnih - op. a.) zarobljenika uvelike znanstveno obrađen na primjerima španjolske reconquiste i križarskih ratova što nije slučaj i u hrvatskoj historiografiji; usp. JURKOVIć 2006: 61, n. 79.

7 Tu pretpostavku potvrđuje i naglo opadanje broja kupoprodajnih ugovora tijekom prvog desetljeća, a potom i potpuno zamiranje takvog vida poslovanja tijekom drugog desetljeća 16. stoljeća. No, prodaja obiteljske plemenšćine nije samo značila spašavanje člana roda, već je istovremeno bila i uzrokom nagloga pada obitelji na društvenoj ljestvici, njezinog ovisništva o solidarnosti ostalih članova roda i trenutnog gubitka gospodarske osnovice i moći. Bez tih se elemenata teško moglo početi s izgradnjom novog života i egzistencije u staroj, a kamoli u novoj i nepoznatoj sredini. Nekoliko slučajeva takva ponašanja hrvatskoga plemstva vidi u: ŠURMıN 1898: 388-389; HORVÁTH et al. 1915: 118-122; LASZOWSKI 1916: 347-348; 1917: 306-309; 1931: 65; BožIć 1952: 326-329; Voje 1992: 323-324; RAUKAR 1997: 411-415; ANDRIĆ 1999: 259-262 i 315-326; ČebotareV 2003.
} 
habsburškim zemljama (današnja Slovenija, sjeverna Italija i Austrija) poklapa se s odumiranjem najkraćih trgovačkih pravaca, koji su preko Hrvatske išli od Jadranskog mora prema Srednjoj Europi (Pickl 1971; 1971a; Raukar 1997: 151-168).

Unutarnja je trgovina Hrvatske također zamrla zbog ratne ugroženosti, posvemašnje depopulacije i gospodarskog odumiranja proizvodnih djelatnosti pa je logistička potpora - pomoć u opskrbi hranom, oružjem i municijom - postala glavnim izvorom poslovanja odnosno svojevrsnim vidom (ne)legalne trgovine. No, takav je tip trgovine bio i ostao u potpunosti ovisnim o vojnoj funkciji čitave regije. Kao rezultat tih procesa gradovi su i gradska naselja od jadranske obale do Drave proživljavala duboku krizu i zastoj u svojemu razvoju (Raukar 1997: 415-425 i 433-439).

Uz te nepovoljne promjene, kontinentalni gradovi tijekom 16. st. nisu više bili dovoljno moćni da u uvjetima ratne privrede vrlo profitabilnu trgovinu poljoprivrednim proizvodima zadrže samo za sebe. Opskrba hranom, kao važan element logističke potpore vojnoj granici, postala je u tom razdoblju vrlo unosan posao i važan izvor financijskih sredstava pa su hrvatska gospoda tijekom 16. st. mijenjala svoj odnos ne samo prema svojim rustikalnim podložnicima, nego i prema žiteljima trgovišta i gradova. Ta se promjena najbolje očituje kroz pitanje prikupljanja feudalnih poreza u naturalnom obliku. Naime, poodmakli se proces pretvorbe naturalnih u novčana podavanja ratnom opasnošću i nesigurnošću u Hrvatskoj naglo zaustavio krajem 15. stoljeća. Inicijatori su vraćanja na stare odnose u to vrijeme bili zapravo seljaci. Oni se zbog osmanske opasnosti nisu osjećali sigurnima na putovima prema udaljenim trgovištima gdje su plasirali svoje poljoprivredne proizvode, pa im je u to vrijeme jednostavnije bilo ponuditi svojemu gospodaru plaćanje poreza u naturi. $U$ tadašnjoj posvemašnjoj oskudici novca hrvatski feudalci nerado su prihvaćali takve ponude svojih kmetova premda su im izlazili ususret pristajući na naturalni vid poreza kao na svojevrstan privilegij, kojim su ih nastojali zadržati na svojim ugroženim posjedima (Adamček 1980: 162190).

No, dolaskom Habsburgovaca na vlast obrambeni se fortifikacijski sustav od tridesetih do sedamdesetih godina 16. st. postupno modernizirao, profesionalizirao i popunjavao kraljevskim vojnim posadama koje su se opskrbljivale hranom sa susjednih teško stradalih vlastelinstava (Adamček 1980; Kruhek 1995). Problem je bio u tome što je potražnja za hranom bila puno veća od same ponude pa je cijena gotovih poljoprivrednih proizvoda naglo rasla. Upravo zato i zbog nestašice radne snage na seoskim dijelovima vlastelinstava, feudalni gospodari gradova započinju tijekom tog razdoblja dokidati povlastice te nametati gradskom stanovništvu uz nove poreze i čista naturalna kmetska podavanja što je, jasno, dovodilo do otvorenih sukoba građana sa svojim gospodarima, a time i do ubrzanijega propadanja samih gradova (Adamček 1980: 396-407). ${ }^{8}$ Te se promjene društvenih odnosa definiraju kao "proces refeudalizacije“ - proces koji je bio potaknut, prije svega, ratnim stanjem, elementarnim nepogodama, godinama gladi i posljedično epidemijama, a koji je rezultirao nestankom robno-novčanih odnosa među podložničkim kmetskim slojem stanovništva, ali i nestankom velikoga broja gradskih naselja (Adamček 1980: 161-190; Kruhek 1995; Raukar 1997: 143-150, 410-411, 433-434 i 458-459).

Stav sličan onomu vlastelinskomu imao je često i sam vladar prema svojim slobodnim kraljevskim gradovima. Primjerice, zagrebački Gradec kao najrazvijenije gradsko središte na teritoriju Hrvatske i Slavonije proživljavao je tijekom 16. st. ozbiljnu krizu. Na temelju gradskih prihoda i rashoda te plaćanja poreznih pristojbi - osobito tridesetine - može se sasvim lijepo vidjeti kako Gradec od sredine 16. st. gospodarski naglo nazaduje i kako nije bio u stanju plaćati ratne izvanredne poreze koje su vladari sve učestalije nametali gradu, iako je Gradec starim privilegijima bio oslobođen tih poreza (KAMPUš 1963; 1967; 1968). 


\section{Rezultat „spirala smrti“ - ratna privreda}

Stare su, dakle, socijalne i gospodarske strukture hrvatskog društva bile uništene konstantnim (malim) ratom, nepovoljnim vremenskim uvjetima, godinama gladi i kužnim epidemijama u razdoblju od pada Bosne pod osmansku vlast pa sve do sloma Korvinova obrambenog graničnog sustava i mukotrpnog uspostavljanja nove habsburške vojne granice (Vojna krajina) tijekom čitava 16. stoljeća (Jurković 2004: 330-331 i 400-412). Ti čimbenici su konačno prouzročili fizičku i psihičku iscrpljenost većine hrvatskog žiteljstva, koje je postupno gubilo volju i nadu da bi se kako tako mogli obraniti njihovi domovi i njihov društveni i socijalni položaj predosmanskog razdoblja. I premda je tijekom tog razdoblja hrvatska plemićka elita ostala bez svojega gospodarskog temelja kao i bez svoje feudalne okosnice, ona je zapravo bila najodlučnijom u obrani i očuvanju njezina predratnog statusa. Članovi nižih slojeva plemstva koji nisu imali jaki gospodarski temelj, pak, bili su prisiljeni migrirati i potražiti mirnije i sigurnije krajeve u kojima se moglo započeti s izgradnjom nove egzistencije i novoga gospodarskog temelja obitelji. No, vrlo često su se i u tim doseljenim sredinama (zapadna i sjeverna Ugarska) opetovano suočavali s osmanskom prijetnjom nakon pada Budima (1541.) pa im je u gospodarskom smislu, poput plemenitih obitelji koje su unutarnjim seobama opstale u Hrvatskoj i Slavoniji, jedina alternativa bila pronalazak posla u okvirima vojnih aktivnosti i ratne privrede kao isključivi način preživljavanja i pronalaska izvora zarade. Kao takvo plemstvo je preko svojih predstavnika u Hrvatskom saboru, pronalazeći putove opstanka i štiteći golu egzistenciju, i izabiralo novu dinastiju 1527. godine - dinastiju Habsburg.

\section{KRATICE}

APJ Arkiv za povjestnicu jugoslavensku

HAZU Hrvatska akademija znanosti i umjetnosti

MHH-D Monumenta Hungariae historica - Diplomataria

MHJSM Monumenta historico-juridica Slavorum meridionalium

MSHSM Monumenta spectantia historiam Slavorum meridionalium

Zbornik OPZ Zbornik Odsjeka za povijesne znanosti Zavoda za povijesne i društvene znanosti HAZU

\section{POPIS LITERATURE}

\section{ADAMČEK 1980}

Josip Adamček, Agrarni odnosi u Hrvatskoj od sredine 15. do kraja 17. stoljeća, Zagreb 1980.

\section{ADAMČEK ET AL. 1976}

Josip Adamček - Ivan Kampuš, Popisi i obračuni poreza u Hrvatskoj u XV i XVI stoljeću, Zagreb 1976.

\section{ANDRIĆ 1999}

Stanko Andrić, Čudesa svetoga Ivana Kapistrana: povijesna i tekstualna analiza, Slavonski Brod-Osijek 1999.

\section{BIRABEN 1975}

Jean N. Biraben, Les hommes et la peste en France et dans les pays européens et mediterranéens, vol. 1: La peste dans l'histoire, Pariz - La Haye 1975.

\section{BIRABEN 1976}

Jean N. Biraben, Les hommes et la peste en France et dans les pays européens et mediterranéens, vol. 2: Les hommes face à la peste, Pariz - La Haye 1976.

\section{BOTICA 2011}

Ivan Botica, Krbavski knezovi u srednjem vijeku, doktorska disertacija na Filozofskom fakultetu Sveučilišta u Zagrebu, Zagreb 2011. 


\section{BOŽıĆ 1952}

Ivan Božić, Dubrovnik i Turska u XIV i XV veku, Beograd 1952.

\section{ČEBOTAREV 2003}

Andrej Čebotarev, „Martolozi kao trgovci robljem od 15. do 18. st.", u: Aleksander Buczynski - Stjepan Matković (ur.), Hereditas rerum Croaticarvm ad honorem Mirko Valentić, Zagreb 2003., 75-84.

\section{ČORALIĆ 2001}

Lovorka Čoralić, U gradu svetoga Marka. Povijest hrvatske zajednice u Mlecima [In the City of St. Mark. A History of the Croatian Society in Venice], Zagreb: Golden marketing, 2001.

\section{FRANKAPAN 2010}

Bernardin Frankapan Modruški, Oratio pro Croatia-Govor za Hrvatsku (1522.), prir. Ivan Jurković - Violeta Moretti, Zagreb 2010.

\section{GESTRIN 1998}

Ferdo Gestrin, Slovanske migracije v Italijo, Ljubljana 1998.

\section{GRGIN 2002}

Borislav Grgin, Počeci rasapa. Kralj Matijaš Korvin i srednjovjekovna Hrvatska, Zagreb 2002.

\section{HODINKA ET AL. 1903}

Antal Hodinka - Lajos Thalóczy, A horvát véghelyek oklevéltára, MHH-D 31, Budimpešta 1903.

\section{HORVÁTH ET AL. 1915}

Sándor Horváth - Lajos Thallóczy, Codex diplomaticus partium Regno Hungariae adnexarum. Banatus, castrum et oppidum Jajcza (14501527), MHH-D 40, Budimpešta 1915.

\section{JURKOVIĆ 1999}

Ivan Jurković, „Turska opasnost i hrvatski velikaši - knez Bernardin Frankapan i njegovo doba", Zbornik OPZ HAZU 17, Zagreb 1999., 61-83.

\section{JURKOVIĆ 2002}

Ivan Jurković, „Raseljena plemićka obitelj za osmanske ugroze: primjer Berislavića de Werhreka de Mala Mlaka (Dio prvi - Stjepan Berislavić Vrhrički i Malomlački)", Zbornik OPZ HAZU 20, Zagreb 2002., 125-164.

\section{JURKOVIĆ 2004}

Ivan Jurković, The Fate of the Croatian Noble Families in the Face of Ottoman Advance, doktorska disertacija na CEU, Budimpešta 2004.

\section{JURKOVIĆ 2006}

Ivan Jurković, „Osmanska ugroza, plemeniti raseljenici i hrvatski identitet", Povijesni prilozi 31, Zagreb 2006., 39-69.

\section{JURKOVIĆ 2008}

Ivan Jurković, „Ugrinovići od Roga - Raseljena obitelj plemenitog roda Šubića Bribirskih za trajanja osmanske ugroze", Zbornik Odsjeka za povijesne znanosti HAZU, vol. 26, Zagreb 2008., 71-85.

\section{KAMPUŠ 1963}

Ivan Kampuš, „Prilog pitanju o poreznom sistemu u Gradecu od XIV do XVI stoljeća“, Radovi FF, Odsjek za povijest 5, Zagreb 1963., 5-26.

\section{KAMPUŠ 1967}

Ivan Kampuš, „Prilog poznavanju tridesetine u XVI st.", Historijski zbornik, god. 19-20, Zagreb 1967., 195-223.

\section{KAMPUŠ 1968}

Ivan Kampuš, „Prilog poznavanju privrednog položaja zagrebačkog Gradeca u XVI. st. na osnovu varoških računa prihoda i rashoda", $R a$ dovi FF, Odsjek za povijest 6, Zagreb 1968., 5-33

\section{KAMPUŠ 1995}

Ivan Kampuš (ur.), Povijest i kultura gradišćanskih Hrvata, Zagreb 1995.

\section{KARBIĆ 1990}

Damir Karbić, „Agrarni odnosi na području Lučke županije krajem XIV. stoljeća“, Historijski zbornik, god. 43, br. 1, Zagreb 1990., 17-24.

\section{KARBIĆ 1998}

Damir Karbić, „Hrvatski plemićki rod i običajno pravo“, Zbornik OPZ HAZU 16, Zagreb 1998., 73-117.

\section{KARBIĆ 2000}

Damir Karbić, The Šubići of Bribir. A Case Study of a Croatian Medieval Kindred, doktorska disertacija na Srednjoeuropskom sveučilištu, Budimpešta 2000. 


\section{KLAIĆ 1972}

Nada Klaić, Izvori za hrvatsku povijest do 1526. godine, Zagreb 1972.

\section{KRUHEK 1995}

Milan Kruhek, Krajiške utvrde i obrana hrvatskog kraljevstva tijekom 16. stoljeća, Zagreb 1995.

\section{KRUHEK 2008}

Milan Kruhek, Srednjovjekovni Modruš: Grad knezova Krčkih-Frankopana i biskupa Krbavskomodruške biskupije, Ogulin 2008.

\section{KUKULJEVIĆ 1857}

Ivan Kukuljević Sakcinski, „Ljetopis fra Šimuna Klimentovića", APJ 4, Zagreb 1857., 30-35; „Ljetopisi fratra Šimuna Glavića“, u: isto, 36-44; "Ljetopis nepoznatoga u talijanskom jeziku“, u: isto, 48-65.

\section{KUKULJEVIĆ 1865}

Ivan Kukuljević Sakcinski, „Rapporti della Republica Veneta con Slavi meridionali. Brani tratti dei diarj manoscritti di Marino Sanudo", APJ 8, Zagreb 1865., 1-256.

\section{KUŽIĆ 2000}

Krešimir Kužić, „Zabilježbe o 'malom ledenom dobu' i njegovim posljedicama u hrvatskim krajevima“, Povijesni prilozi 18, Zagreb 2000., 373-404.

\section{LADURIE 1972}

Emmanuel Le Roy Ladurie, Times of Feast, Times of Famine: A History of Climate since the Year 1000, London 1972.

\section{LASZOWSKI 1914}

Emilij Laszowski, Monumenta Habsburgica Regni Croatiae Dalmatiae et Slavoniae (15261530.), vol. 1, MSHSM 35, Zagreb 1914.

\section{LASZOWSKI 1916}

Emilij Laszowski, Monumenta Habsburgica Regni Croatiae Dalmatiae et Slavoniae (15311540.), vol. 2, MSHSM 38, Zagreb 1916.

\section{LASZOWSKI 1917}

Emilij Laszowski, Monumenta Habsburgica Regni Croatiae Dalmatiae et Slavoniae (15441554.), vol. 3, MSHSM 40, Zagreb 1917.

\section{LOPAŠIĆ 1894}

Radoslav Lopašić, Hrvatski urbari - Urbaria lingua Croatica conscripta, MHJSM 5, Zagreb 1894.

\section{LJUBIĆ 1876}

Simeon Ljubić, Commissiones et relationes Venetae. Annorum 1433-1527, tom. 1, MSHSM 6, Zagreb 1876.

\section{LJUBIĆ 1877}

Simeon Ljubić, Commissiones et relationes Venetae. Annorum 1525-1553, tom 2, MSHSM 8, Zagreb 1877.

\section{PICKL 1971}

Othmar Pickl, „Die Auswirkungen der Türkenkriege auf den Handel zwischen Ungarn und Italien im 16. Jahrhundert", u: Othmar Pickl (ur.), Die wirtschaftlichen Auswirkungen der Türkenkriege, Graz 1971., 71-129.

\section{PICKL 1971A}

Othmar Pickl, „Der 'Dreißigst in Windischland'. Organisation und Ertrag des ungarischen Außenhandelszolles in Oberslawonien im 16. Jh", Zeitschrift des Historischen Vereins für Steiermark 18, Graz 1971., 157-178.

\section{RAUKAR 1997}

Tomislav Raukar, Hrvatsko srednjovjekovlje. Prostor, ljudi, ideje, Zagreb 1997.

\section{ŠURMIN 1898}

Đuro Šurmin, Acta Croatica - Hrvatski spomenici l, od 1100-1499., MHJSM 6, Zagreb 1898.

\section{VOJE 1992}

Ignacij Voje, „Migracijski procesi v slovenskem prostoru $v$ turškem obdobju (16 do 18 stoletje)“, Zgodovinski časopis, let. 37, št. 3, Ljubljana 1992., 323-333. 


\section{SAŽETAK}

Osiromašeno gospodarstvo hrvatskih zemalja u razdoblju od pada Bosne pod osmansku vlast pa do trenutka kada Korvinov obrambeni protuosmanski granični sustav (1463.-1527.) kolabira, postupno poprima gotovo apokaliptične dimenzije. $U$ to su vrijeme klimatske promjene i nepovoljne zdravstvene prilike žiteljstva dovodile do demografskih i gospodarskih nestabilnosti, ne samo u Hrvatskoj, već i na širem području tadašnjeg Mediterana. Hrvatski su kroničari, kao i državni službenici u svojim dramatičnim izvješćima, opisivali posljedice neuobičajeno oštrih i dugih zima, ljude iznurene glađu i masovna umiranja tijekom kužnih epidemija. Spominju se uništeni i zaleđeni usjevi, maslinici i vinogradi ili smrznute bačve vina, ali i vina koje se ledilo u kaležima pod sv. misom (!), a ljudima su prema tim vijestima otpadali smrznuti nosovi, prsti i uši. Opisuju se također ljudi koji iznureni od gladi bauljaju po gradovima i prose koricu kruha ili bilo kakvu hranu te jedu travu i koru s drveća, ali i užasna pustošenja kuge te ljudi koji bezglavo bježe iz kugom pogođenih mjesta.

Zamršenost gospodarskih i društvenih odnosa tijekom tog razdoblja jednostavno onemogućava detaljan prikaz svih uzroka gospodarskog nazadovanja i propadanja hrvatskih zemalja. Pa ipak, moraju se istaknuti najvažniji i u povijesnim procesima najvidljiviji mehanizmi krize koji uzrokuju potpuni gospodarski slom srednjovjekovne Hrvatske: 1) ratovi kršćanskih i osmanske države koji su se vodili na hrvatskim teritorijima; 2) sve učestaliji pljačkaški pohodi osmanskih (ne)regularnih postrojbi na hrvatskim područjima („mali rat“); 3) zdravstvene (ne)prilike (kuga i druge pošasti); 4) klimatske promjene koje su nastupale od kraja 15. st. („malo ledeno doba“); 5) posvemašnja depopulacija središnjih hrvatskih područja kao rezultat prethodno spomenutih čimbenika.

\section{SUMMARY}

\section{Model of Causal Relationships of the Ottoman Threats, Climate Disasters, Famine, and Plague on the Economy of Croatian and Slavonian Noble Estates During the Last Decades of the $15^{\text {th }}$ and Through the $16^{\text {th }}$ Century}

The crisis of the economy of Croatian territories in the period from the fall of Bosnia under Ottoman rule to the collapse of the anti-Ottoman frontier defense system (14631527) progressively assumed almost apocalyptic dimensions. At that time climatic changes and unfavorable health conditions of the population led to depopulation and economic instability, not only in war endangered Croatia, but throughout the Mediterranean. Croatian chroniclers, as well as state officials, described the effects of the unusually harsh and long winters, people exhausted by famine, and mass mortality during plague epidemics in their dramatic accounts. Frozen and devastated crops, olive-groves and vineyards, as well as wine frozen in barrels or even in chalices during the holy mass are mentioned, while it was said that people's noses, ears, and fingers fell off due to frostbite. They also describe people stumbling around begging for bread and food or eating grass and bark from trees, continuing this kind of accounts with descriptions of the ravaging of the plague and people running away from plague-stricken places in horror.

The complicated economic and social relationship of that area renders it impossible to offer a detailed account of all the reasons behind the decline and decay of the Croatian economy. Still, the most important, and in the historical process the most visible, causes of the crisis that brought about the complete breakdown of medieval Croatia must be 
emphasized. They were as follows: 1) the wars between the Christian and Ottoman states fought on Croatian lands; 2) the ever-increasing marauding raids by Ottoman troops on Croatian territory (the "small war"); 3) health conditions (plagues and other epidemics); 4) climatic changes which appeared towards the end of the fifteenth century (the "little ice age "); 5) widespread depopulation of the interior of Croatia as a result of the aforementioned conditions.

Keywords: Ottoman threat, plagues and other epidemics, climatic changes, depopulation, economy, Croatia and Slavonia 